\title{
Use of the double Thiry-Vella loop in the study of the effects of pantothenic acid on intestinal absorption of glucose
}

\author{
By PHAN HOANG HUAN AND LE VAN HUNG \\ Laboratory of Physiology of Nutrition, \\ Faculty of Sciences, Sorbonne, Paris
}

(Received 1o February 1972-Accepted 10 May 1972)

\begin{abstract}
I. The double Thiry-Vella loop operation was successfully performed in the rat with the formation of two $200 \mathrm{~mm}$ jejunal segments, thus isolating one-half of the small intestine.

2. Using this preparation a comparative in vivo study of the effects of pantothenic acid on glucose absorption was carried out.

3. Pantothenic acid increased glucose absorption by local action on the mucous surface of the intestine. This vitamin appears to be part of a glucose carrier system, in a labile form different from coenzyme A.
\end{abstract}

Experiments involving the role of vitamins in intestinal absorption are often carried out by subjecting the experimental animal to a diet that is deficient in the vitamin under investigation (Bly, Heggness \& Nasset, I943; Althausen, Eiler \& Stockholm, 1946). This technique requires a number of reservations to be made in the interpretation of the results, since the metabolic disturbances that ensue are difficult to analyse because they involve modifications both in the functioning of cells in general (Terroine, I966) and in absorption by the mucosal cell in particular (Althausen et al. x946). It was thought that if, before the experiment, the animal involved were given a balanced diet the study of the effects of a vitamin injected in known amounts into its intestine would provide results that would be unequivocal and more significant.

A demonstration of the stimulation of intestinal absorption of glucose by pantothenic acid in the normal rat was shown under these conditions (Phan Hoang Huan \& Le Van Hung, 1968). In an effort to elucidate the mechanism of action of this vitamin, the present study was undertaken to determine whether pantothenic acid absorbed at the same time as the glucose by an isolated intestinal loop would affect the rest of the intestine. It was thought that the possibility of studying the rate of glucose absorption both in the presence and absence of this vitamin in intestinal loops of the same animal would enable this to be done.

A method of studying intestinal absorption in vivo is the technique of the double Thiry-Vella loop. This device permits simultaneous perfusion of two intestinal loops in the same rat by independent circuits, and thus enables a comparison to be made of the rates of absorption in relation to the composition of the perfusate. In this way it was possible to identify the general or local effect of pantothenic acid on glucose absorption. 
EXPERIMENTAL

Six male Wistar rats weighing from 250 to $300 \mathrm{~g}$ were used. Before the operation or the intestinal perfusion experiment, they were placed on a liquid diet for $16 \mathrm{~h}$.

\section{Preparation of the double Thiry-Vella loop}

The double Thiry-Vella loop is composed of two adjacent jejunal segments each $200 \mathrm{~mm}$ long. The technique of isolating the two loops is identical to that used in establishing the single Thiry-Vella loop; the continuity of the intestinal tract is re-established by the same operating technique using a modified Lembert suture and an easily digestible internal support (Phan Hoang Huan \& Le Van Hung, 1966). Twelve days after the operation the rat is perfectly capable of supporting double perfusion experiments. Radiographs of loops isolated in this manner show clearly their regular and normal appearance after several perfusions (P1. г $a, b$ ). Entry and exit nozzles for the perfusate are secured by plain 'crocodile' type clamps (Pl. I $c$ ).

\section{Method of perfusion}

Four-hour open-circuit perfusions were made by the technique described by Phan Hoang Huan \& Le Van Hung (1968); the flow-rate through the loops was $4.5 \mathrm{ml} / \mathrm{h}$. Pantothenic acid was added to a $4 \%(\mathrm{w} / \mathrm{v})$ glucose solution at a concentration of $2.09 \mu \mathrm{mol} / \mathrm{ml}$. The resulting perfusate was collected in $5 \mathrm{ml}$ graduated tubes containing $5 \mathrm{mg}$ of solid sodium fluoride; tubes were changed every hour.

In an initial series of experiments, both loops were perfused either with the glucose solution alone or with a solution of glucose and pantothenic acid. In a second series of experiments, the first loop was perfused with the glucose solution, and the second with the same solution plus pantothenic acid. The same six rats were used in all experiments.

Intestinal absorption was calculated as the difference between the amounts of glucose injected into the intestinal loop and the amounts collected at the exit, and was expressed as $\mathrm{mg}$ glucose $/ \mathrm{h}$ perfusion for each $200 \mathrm{~mm}$ length of intestine.

\section{Glucose determination}

Glucose was determined by the Hoffman (1937) method adapted to a Technicon AutoAnalyzer (Technicon Instruments Co. Ltd, Basingstoke, Hants). The yellow solution of potassium ferricyanide was reduced to the colourless ferrocyanide in the presence of glucose. The colour was measured at $420 \mathrm{~nm}$ using a flow-cell having a $5 \mathrm{~mm}$ light path.

\section{RESULTS}

The animals carrying the double Thiry-Vella loop had no digestive problems and gained weight normally. They lived for 2-2.5 years after the operation. Rates of glucose absorption by the Thiry-Vella loops were comparable for the 2 months of the experiment. However, after 6 months of disuse the intestinal loops atrophied, and after I year they were reduced to plain bands, especially where their openings were closed to the surface of the skin. 
Table I. Simultaneous infusion of individual rats, by means of a double Thiry-Vella loop, with $(A)_{4} \%$ glucose solution into both loops, $(B) 4 \%$ glucose solution + pantothenic acid (2.09 $\mu \mathrm{mol} / \mathrm{ml})$ into both loops, and $(C)_{4} \%$ ghcose solution into the first loop and $4 \%$ ghcose solution + pantothenic acid $(2 \cdot 09 \mu \mathrm{mol} / \mathrm{ml})$ into the second loop

(The perfusion lasted for $4 \mathrm{~h}$; each value is the mean of the readings obtained after each hour)

\begin{tabular}{|c|c|c|c|c|c|c|}
\hline \multirow[b]{3}{*}{ Rat no. } & \multicolumn{6}{|c|}{ Glucose absorbed (mg/h of perfusion) } \\
\hline & \multicolumn{2}{|c|}{ A } & \multicolumn{2}{|c|}{$\mathrm{B}$} & \multicolumn{2}{|c|}{$\mathbf{C}$} \\
\hline & First loop & Second loop & First loop & Second loop & First loop & Second loop \\
\hline I & 105.0 & $97 \cdot 5$ & $136 \cdot 5$ & $127 \cdot 5$ & $109 \cdot 5$ & $\mathrm{r}_{3} \mathrm{x}-8$ \\
\hline 2 & $98 \cdot 8$ & $106 \cdot 3$ & $14 \mathrm{I} \cdot 8$ & 142.5 & $100 \cdot 0$ & $45 \cdot 8$ \\
\hline 3 & IOI'3 & $95^{\circ} 0$ & 123.8 & I $37 \% 5$ & $114 \cdot 3$ & $146 \cdot 8$ \\
\hline 4 & II $3 \cdot 8$ & IO2.5 & 140.0 & $\mathrm{r} 27.5$ & $\times 55$ & $122 \cdot 0$ \\
\hline 5 & 105.0 & $107 \cdot 5$ & $122 \cdot 5$ & I $12 \cdot 5$ & $102 \cdot 8$ & I $16 \cdot 0$ \\
\hline 6 & $\operatorname{IIx} \cdot 3$ & $99 \cdot 5$ & $135^{\circ} \mathrm{O}$ & I $35 \cdot 0$ & $116 \cdot 3$ & $120 \cdot 8$ \\
\hline Mean & $105^{\circ} 9$ & ror 4 & 1324 & 130.4 & 1097 & $x 30.5$ \\
\hline \multicolumn{2}{|c|}{ Mean difference } & 45 & \multicolumn{2}{|c|}{$2 \cdot 0$} & \multicolumn{2}{|c|}{$-20 \cdot 8$} \\
\hline $\mathrm{SE}$ & & $3 \cdot 2$ & \multicolumn{2}{|c|}{$4 \cdot 2$} & \multicolumn{2}{|c|}{$6 \cdot 6$} \\
\hline $\begin{array}{l}\text { Significar } \\
\text { differer }\end{array}$ & $\begin{array}{l}\text { of } \\
\text { (single }\end{array}$ & NS & \multicolumn{2}{|c|}{ NS } & \multicolumn{2}{|c|}{$P<0.02$} \\
\hline
\end{tabular}

difference (single tail test) between loops

NS, not significant.

The results of the experiments are presented in Table $\mathrm{I}$. As can be seen, the rate of glucose absorption by the two loops was identical. When pantothenic acid was added to the glucose solution the increase in the rate of glucose absorption was similar in the two loops. In the second series of experiments, glucose absorption from the second loop increased whereas that from the first loop remained stable.

\section{DISCUSSION}

The double Thiry-Vella loop made possible a comparative study of intestinal absorption in a single rat. In view of the variation between animals in physiological responses, the ability to carry out repeated perfusion experiments on the same animal reduces individual variations, part of which results from differences in the thickness of the intestinal wall; in the rat this may vary from $0.30 \mathrm{~mm}$ in the upper jejunum to $0.15 \mathrm{~mm}$ in the lower ileum (Wilson \& Wiseman, 1954). Thus in our perfused Wistar CF rats the $200 \mathrm{~mm}$ length of fresh intestine weighed from $\mathrm{r} \cdot 4$ to $\mathrm{r} \cdot 6 \mathrm{~g}$.

The normal development of rats carrying the double Thiry-Vella loop demonstrated that these animals could withstand the isolation of a $400 \mathrm{~mm}$ length of small intestine in its jejunum. 'These findings agree with those of authors who studied the massive resection of the upper parts of the intestine (Derblom, Nylander \& Olerud, I962; Nylander \& Olerud, I 962). In their histological studies, they found that the intestines of the experimental animals were normal in structure, and their growth rate was comparable to that of the controls. However, no observations were made of isolated 
intestinal loops in the rat. A histological study of the Thiry-Vella loops has yet to be made, but the results obtained in the present series of experiments appear to confirm that they function normally. Table I shows that the upper and lower sections of the jejunum absorbed glucose in an identical manner and that pantothenic acid stimulated absorption equally in both loops.

In the second experiment one might suppose that the pantothenic acid present in the second loop which, like most water-soluble vitamins, is passively absorbed (Turner \& Hughes, r962; Spencer \& Bow, 1964) would reach the first loop in the general circulation and activate the rate of glucose absorption there. However, the results presented in Table $I$ make it clear that this activation occurred only in the loop in which the pantothenic acid was present. One explanation of this fact is that the pantothenic acid might be transformed in the liver as soon as it is absorbed in the presence of glucose. However, in similar experiments it was observed that the concentration of free pantothenic acid in the liver increased whereas that of coenzyme $A$ decreased (Phan Hoang Huan and Le Van Hung, unpubiished). Furthermore, coenzyme $A$, when added in small amounts to the perfusate, does not modify the level of intestinal absorption of glucose; larger doses of this coenzyme, however, have an inhibiting effect on absorption (Phan Hoang Huan \& Le Van Hung, 1972). These results suggest that free pantothenic acid participates in a glucose carrier system inside the mucosal cells.

It is concluded that pantothenic acid stimulates glucose absorption by a local action at the brush border of the intestinal cells.

\section{REFERENCES}

Althausen, T. L., Eiler, J. J. \& Stockholm, M. (1946). Gastroenterology 7, 469.

Bly, C. G., Heggness, F. W. \& Nasset, E. S. (r943). F. Nutr. 26, I6r.

Derblom, H., Nylander, G. \& Olerud, S. (1962). Acta chir. scand. 123, 57.

Hoffman, W. S. (1937). F. biol. Chem. 120, 5 I.

Nylander, G. \& Olenud, S. (1962). Acta chir. scand. 123, 5 I.

Phan Hoang Huan \& Le Van Hung (1 966). Archs Sci. physiol. 2o, 13 I.

Phan Hoang Huan \& Le Van Hung (1968). Archs Sci. physiol. 22, 183.

Phan Hoang Huan \& Le Van Hung (1972). C. r. Séanc. Soc. Biol. (In the Press.)

Spencer, R. P. \& Bow, T. M. (1964). F. nucl. Med. 5, 25 I.

Terroine, 'Th. (1966). Les Intervelations vitaminiques p. 99. Paris: Centre National de la Recherche Scientifique.

Turner, J. B. \& Hughes, D. E. (1962). Q. Il exp. Physiol. 47, 107.

Wilson, T. H. \& Wiseman, G. (1954). भ. Physiol., Lond. 123, 126.

EXPLANATION OF PLATE

Radiographs showing $(a)$ the first and $(b)$ the sccond loops of the double Thiry-Vella loop in a rat, and (c) perfusion of a rat by a double Thiry-Vella loop. 

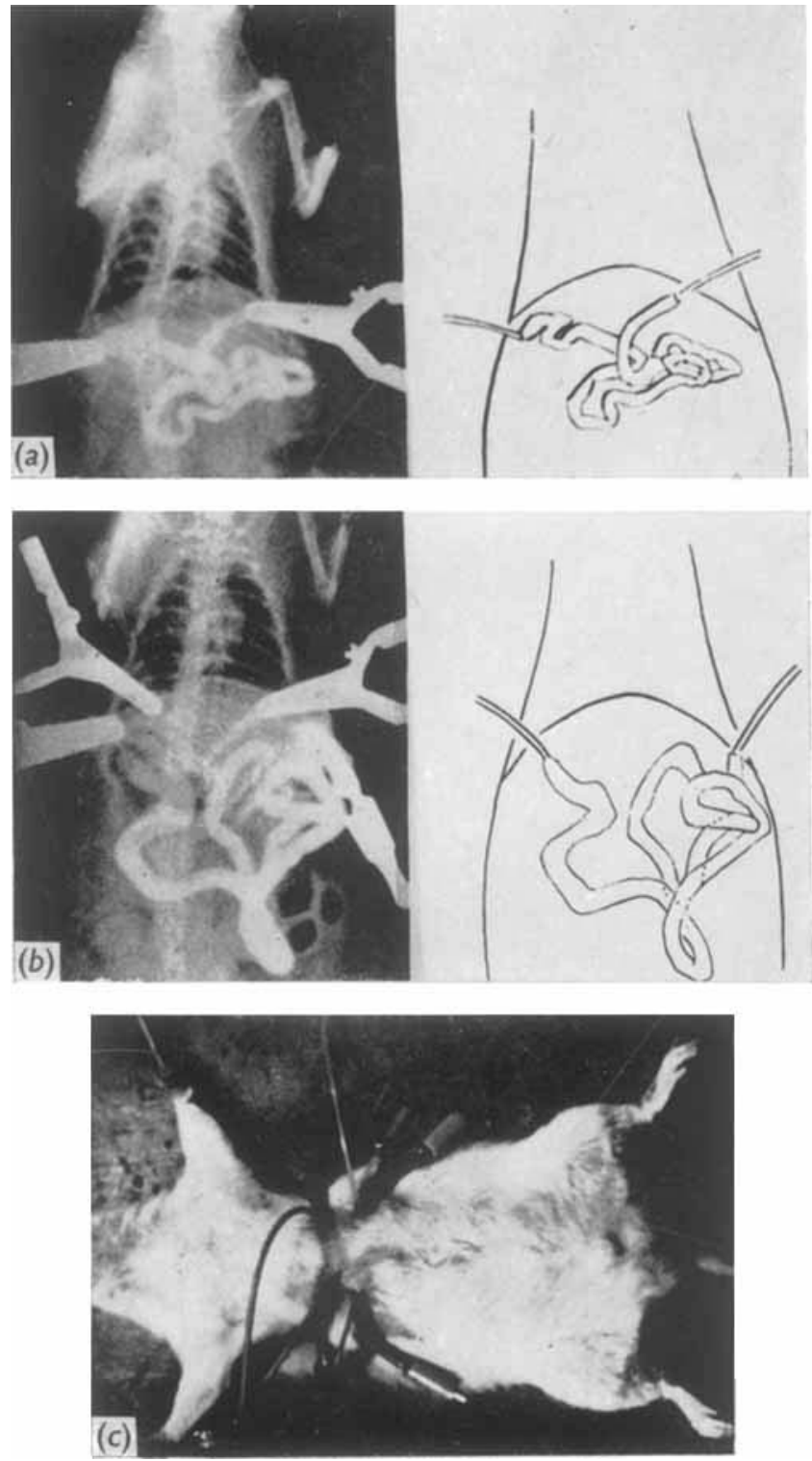

PHAN HOANG HUAN AND TE VAN IIUNG 